\title{
PENGARUH SOCIAL MEDIA MARKETING ACTIVITIES TERHADAP BRAND LOYALTY \\ Efek Mediasi Brand Consciousness dan Value Consciousness (Studi Pada Pelanggan Kopi Janji Jiwa di Kota Surakarta)
}

\author{
Sasa Handayani Luhur ${ }^{1}$ \\ Bambang Nur Cahyaningrum ${ }^{2}$ \\ Andiyas Miawan ${ }^{3}$
}

\author{
Fakultas Ekonomi Manajemen, Universitas Veteran Bangun Nusantara \\ Sukoharjo ${ }^{123}$ \\ sasahandayani14@gmail.com ${ }^{1}$ \\ bambangnurcahyaningrum@gmail.com ${ }^{2}$ \\ sarahafina2015@gmail.com ${ }^{3}$
}

\begin{abstract}
ABSTRAK
Penelitian ini bertujuan untuk menguji pengaruh social media marketing activities terhadap brand loyality dan efek mediasi brand consciousness dan value consciousness, dengan studi kasus pada konsumen kopi Janji Jiwa di kota Surakarta. Sampel yang digunakan dalam penelitian ini adalah 109 responden, dengan kriteria konsumen yang mengetahui tentang kopi merek Janji Jiwa, konsumen yang melakukan pembelian produk Kopi Janji Jiwa dikawasan Kota Surakarta, dan konsumen yang mengikuti akun media sosial Instagram atau Facebook Kopi Janji Jiwa. Teknik analisis yang digunakan dalam penelitian ini adalah teknik Structural Equation Modelling (SEM), program aplikasi yang digunakan adalah Analysis Of Moment Structur (AMOS). Penyebaran kuesioner dilakukan secara daring menggunakan Google Form. Hasil penelitian menunjukkan bahwa Social media marketing activities berpengaruh terhadap brand consciousness dan value consciousness, Brand consciousness berpengaruh terhadap brand loyalty, social media marketing activities dan value consciousness tidak berpengaruh terhadap brand loyalty. Brand consciousness memediasi pengaruh social media marketing activities terhadap brand loyalty. Value consciousness tidak memediasi pengaruh social media marketing activities terhadap brand loyalty.
\end{abstract}

Keyword : Social media marketing activities, Brand consciousness, Value consciousness, Brand Loyalty. 


\section{PENDAHULUAN}

Bisnis kopi di Indonesia kian digandrungi oleh masyarakat Indonesia. Hal itu terlihat dari menjamurnya bisnis kopi yang bisa ditemukan di kota-kota besar. Ramainya bisnis tersebut karena meminum kopi kini sedang menjadi gaya hidup warga milenial di Tanah Air (economy.okezone.com, 2020). Bisnis kopi kekinian yang menjamur dengan kemunculan merek-merek kopi lokal di Indonesia menimbulkan persaingan yang berat antara kopi lokal maupun kopi internasional yang berebut minat konsumen Indonesia (bisnis.com, 2019). Untuk membuat bisnis kopi tetap kuat dan bisa berkembang di tengah-tengah ketatnya persaingan maka dapat melakukan beberapa cara seperti menjaga identitas bisnis dengan menyajikan produk yang memiliki khas tersendiri, melakukan inovasi dengan rajin menciptakan menu baru maupun melakukan inovasi pada sistem pelayanan dengan menghadirkan pengalaman memesan kopi tanpa antri melalui aplikasi pesan antar secara online, dan melakukan promosi melalui media sosial seperti Instagram dan Facebook, maupun memasang promo menarik seperti beli satu gratis satu dan diskon di hari spesial (kontan.co.id, 2019). Cara tersebut dilakukan untuk menarik minat konsumen baru dan juga meningkatkan brand loyalty.

Mayoritas konsumen Indonesia menggunakan waktunya berselancar di media sosial untuk mencari produk yang sedang hits/kekinian, hal tersebut mendorong pelaku bisnis untuk melakukan kegiatan pemasaran di media sosial dalam mempromosikan produk dan memungkinkan media sosial menjadi penghubung bagi para konsumen dan pelaku usaha. Hal tersebut memiliki dampak bagi peralihan penggunaan sarana pemasaran tradisional menjadi pemasaran melalui media sosial. Kegiatan pemasaran harus diperhatikan oleh pelaku usaha untuk mendapatkan loyalitas konsumen. (Ismail. 2017). Asosiasi Penyelenggara Jasa Internet Indonesia (APPJI) menyatakan platform media sosial yang paling sering dikunjungi masyarakat Indonesia adalah Facebook 50,7 \%, Instagram 17,8 $\%$, Youtube 15,1\%, sisanya mengunjungi Twitter, Linkedin, dan lainya (APPJI, 2018).

Kegiatan pemasaran yang dilakukan perusahaan melalui media sosial akan menimbulkan brand consciousness dan value consciousness pada konsumen yang 
akan mempengaruhi loyalitas merek. Teori penyelesaian-diri simbolis mendukung gagasan bahwa konsumen menggunakan merek sebagai sarana untuk melindungi identitas diri mereka. Sebagai contoh, konsumen yang sangat sadar merek dapat membeli merek mahal dan tetap loyal kepada merek bukan karena persepsi kualitas semata, tetapi karena orang lain mungkin menganggapnya positif secara sosial karena tingginya harga (Bao dan Mandrik, 2004).

Tidak semua konsumen percaya bahwa membeli produk adalah pendorong kebahagiaan dan pertanda status sosial. Pelanggan yang sadar nilai cenderung peduli sama tentang harga rendah dan kualitas produk (Sharma, 2011 ). Mereka cenderung lebih terbiasa menggunakan platform media sosial untuk berbelanja dengan biaya terendah yang membawa sejumlah manfaat signifikan, yaitu menghemat uang dengan memungkinkan mereka mencapai harga terendah, mengidentifikasi produk yang tepat untuk memenuhi kebutuhan mereka dan membandingkan harga dari berbagai merek. Sehingga konsumen menjadi tidak loyal terhadap suatu merek (Ismail, 2017).

Kopi Janji Jiwa merupakan perusahaan yang bergerak di bidang makanan dan minuman yang didirikan oleh Billy Kurniawan. Pertumbuhan Kopi Janji Jiwa sebagai wujud visi dan misi untuk memberikan sajian minuman kopi yang berkualitas bagi pelanggan, dapat diterima oleh seluruh kalangan dan dapat berkembang ke mancanegara. Tidak hanya itu, seluruh biji kopi yang digunakan oleh Kopi Janji Jiwa dibeli langsung dari para petani Indonesia, yang juga dapat meningkatkan kesejahteraan para petani kopi di Indonesia (Tim MURI, 2019).

Penelitian yang dilakukan oleh Ismail (2017) mengemukakan bahwa brand loyalty, brand conciousness, dan value consciousness. Social media marketing activities yang diterapkan oleh perusahaan telah meningkatkan brand loyality, brand conciousness, dan value consciousness. Konsumen menjadi lebih loyal kepada merek, karena tedapat pemasaran melalui media sosial. Konsumen semakin sadar akan gambar, kualitas, dan atribut terkait dengan nama suatu merek perusahaan, berkat kegiatan pemasaran di meda sosial yang dilakukan. Disamping itu konsumen semakin sadar dengan keseimbangan harga dengan kualitas produk. 
Penelitian yang dilakukan Hidajat dan Keni (2019) mengemukakan bahwa brand consciousness memediasi hubungan antara social media marketing activities dengan brand loyalty. Seperti yang dinyatakan sebelumnya, kegiatan di platform media sosial menawarkan peluang merek untuk berkembang dan meningkatkan brand consciousness.

Penelitian yang dilakukan Larasati et. al. (2019) mengemukakan bahwa value consciousness memediasi hubungan antara social media marketing activities dan brand loyalty. Social Media Marketing Activities dapat meningkatkan value consciousness, dan value consciousness berkaitan secara negatif dengan brand loyalty. Hal tersebut terjadi ketika konsumen yang sadar nilai, akan cenderung memilih alternatif merek dengan kualitas yang sesuai nilai produk atau layanan.

Penelitian ini merupakan replikasi dari riset yang dilakukan oleh Ismail (2017). Perbedaan dengan penelitian terdahulu adalah pada sampel dan karakteristik responden. Pada penelitian terdahulu menggunakan sampel mahasiswa pemasaran di University of Northern Malaysia dengan karakteristik sebagai berikut: pernah menggunakan situs media sosial apa pun, frekuensi penggunaan media sosial, dan anggota komunitas merek dalam platform media sosial diubah menjadi konsumen kopi Janji Jiwa di Kota Surakarta yang mengikuti salah satu akun media sosial Kopi Janji Jiwa (Instagram atau Facebook).

\section{KAJIAN PUSTAKA DAN PENGEMBANGAN HIPOTESIS}

\section{Brand Loyality}

Brand loyalty adalah kegiatan pembelian berulang oleh konsumen dalam suatu periode waktu tertentu dengan emosi positif. Konsumen memiliki kecenderungan untuk memilih suatu merek dibandingkan dengan merek alternatif, merek substitusi, dan merek pesaing. Sasmita dan Suki (2014).

\section{Social Media Marketing Activities}

Penelitian yang dilakukan oleh Ismail (2017) dan Ismail et al, (2018) mengemukakan bahwa Social Media Marketing Activities mempunyai pengaruh positif dan signifikan terhadap Brand Loyalty. Social Media menjadi alat untuk 
mempromosikan produk dan jasa yang memungkinkan pemasar dapat berkomunikasi dengan konsumen secara aktif. Komunikasi berbasis media sosial ini menyediakan informasi yang relevan tentang merek dan mengurangi upaya konsumen dalam mencari informasi lain (Merisavo dan Raulas, 2004). Selain itu memungkinkan konsumen menyuarakan pendapat tentang kepuasan maupun ketidakpuasan suatu produk, jika konsumen menanggapi iklan melalui media sosial secara positif maka hubungan antara konsumen dengan merek akan berkembang. Hal ini menimbulkan hubungan yang kuat antara konsumen dengan merek di media sosial yang mengarah kepada Brand Loyalty. Konsumen menghargai komunikasi merek yang teratur melalui internet, sehingga hal tersebut dapat meningkatkan brand loyalty. (Ismail, 2017). Oleh karena itu penelitian ini menghipotesiskan bahwa:

H1. Social Media Marketing Activities berpengaruh positif terhadap Brand Loyalty.

\section{Brand Consciousness}

Berbagai perusahaan membangun merek melalui platform baik menggunakan Instagram dan Facebook untuk memposting foto sebagai cara promosi, Twitter untuk menghasilkan tren tertentu dengan menggunakan tagar, bahkan melakukan peluncuran produk sebuah merek melalui Youtube. Hal tersebut berdampak pada perilaku pelanggan yang merespon secara proaktif terhadap jejaring sosial, sehingga membuat keterlibatan pelanggan lebih baik dan meningkatkan interaktivitas (Mangold \& Faulds, 2009). Oleh karena itu penelitian ini menghipotesiskan bahwa:

H2. Social Media Marketing Activities berpengaruh positif terhadap Brand Consciousness.

Penelitian yang dilakukan Hermanus et. al. (2019) dan Ismail et. al. (2018) menyatakan bahwa brand consciousness dapat meningkatkan brand loyalty. Akhtar, et al. menjelaskan bahwa brand consciousness dianggap sebagai unsur pengetahuan tentang merek. Ketika konsumen mengetahui tentang merek pada suatu produk, maka mereka akan membeli merek tersebut lagi dan lagi. Pengetahuan tentang merek dan pendapat terhadap merek digunakan untuk 
meningkatkan brand consciousness. Apabila konsumen memiliki pengetahuan tentang merek dan mereka sadar akan merek pada suatu produk tersebut maka mereka akan terus membeli dan setia terhadap merek. Oleh karena itu penelitian ini menghipotesiskan bahwa:

H3. Brand Consciousness berpengaruh signifikan terhadap Brand Loyalty.

\section{Value consciousness}

Penelitian yang dilakukan Ismail et. al. (2018) dan Larasati et. al. (2019) menyatakan bahwa social media marketing activities memunculkan value consciousness konsumen. Konsumen hemat lebih sadar akan nilai dengan mengelola sumber daya dengan hati-hati dan menghindari pemborosan. Konsumen sadar nilai cenderung memperhatikan suatu produk dengan harga rendah dan kualitas yang sama (Sharma dalam Ismail, 2017). Konsumen cenderung terbiasa menggunakan media sosial untuk berbelanja dengan biaya terendah dan memiliki manfaat yaitu (1) menghemat uang dengan memungkinkan konsumen mencapai harga terendah (2) mengidentifikasi produk yang tepat untuk memenuhi kebutuhan (3) membandingkan harga dari berbagai merek . Sehingga mendapatkan barang dengan harga lebih rendah relatif penting daripada kualitas produk maupun citra merk dalam keputusan pembelian. ( Ismail et. al. , 2018). Oleh karena itu penelitian ini menghipotesiskan bahwa:

H4. Social media marketing activities berpengaruh positif terhadap value consciousness

Hermanus et al. (2018) dan Larasati et. al. (2019) menyatakan bahwa persepsi harga yaitu Value Consciousness dapat menurunkan tingkat Brand Loyalty. Tidak semua konsumen percaya bahwa membeli produk adalah pendorong kebahagiaan dan pertanda status sosial. Pelanggan yang sadar nilai cenderung peduli sama tentang harga rendah dan kualitas produk (Sharma dalam Ismail, 2017). Konsumen yang sadar nilai akan memastikan bahwa uang yang mereka keluarkan untuk membeli sebuah produk harus sesuai dengan nilai dari produk tersebut (Rahmadiane, 2016). Konsumen akan cenderung memilih merek alternatif dengan harga lebih murah dan batas kualitas yang relatif sama dengan merek tersebut, artinya konsumen akan cederung mengubah loyalitas dari merek yang sering dibeli menuju merek lain yang menawarkan harga yang lebih murah (Hermanus et., al., 2019). Oleh karena itu penelitian ini menghipotesiskan bahwa: 
https://journal.univetbantara.ac.id/index.php/jbfe

H5. Value Consciousness berpengaruh negatif terhadap Brand Loyalty.

\section{Brand Consciousness}

Penelitian yang dilakukan (Hermanus et., al., 2019) dan Hidajat dan Keni (2019) mengemukakan Brand Consciousness memediasi hubungan antara Social Media Marketing Activities dan Brand Loyalty. Seperti yang dinyatakan sebelumnya, kegiatan di platform media sosial menawarkan peluang merek untuk berkembang dan meningkatkan brand consciousness. Demikian pula, Social Media Marketing Activities berkontribusi terhadap brand loyalty,ketika konsumen sangat sadar tentang merek. (Ismail, 2017). Oleh karena itu penelitian ini menghipotesiskan bahwa:

H6. Brand Consciousness akan memediasi hubungan antara Social Media Marketing Activities dan Brand Loyalty.

Penelitian yang dilakuakan Ismail (2017) dan Larasati et. al. (2019) mengemukakan Value Consciousness memediasi hubungan antara SocialMedia Marketing Activities dan Brand Loyalty. Maka, antara SocialMedia Marketing Activitiesddapat meningkatkan value consciousness dan value consciousness akan dikaitkan secara negatif dengan brand loyalty, hal tersebut terjadi ketika konsumen yang sadar nilai akan cenderung memilih alternatif merek dengan kualitas yang sama (Ismail, 2017). Oleh karena itu penelitian ini menghipotesiskan bahwa:

H7. Value consciousness memediasi hubungan antara Social Media Marketing Activities dan Brand Loyalty

Berdasarkan uraian di atas dapat dibuat model penelitian sebagai berikut:

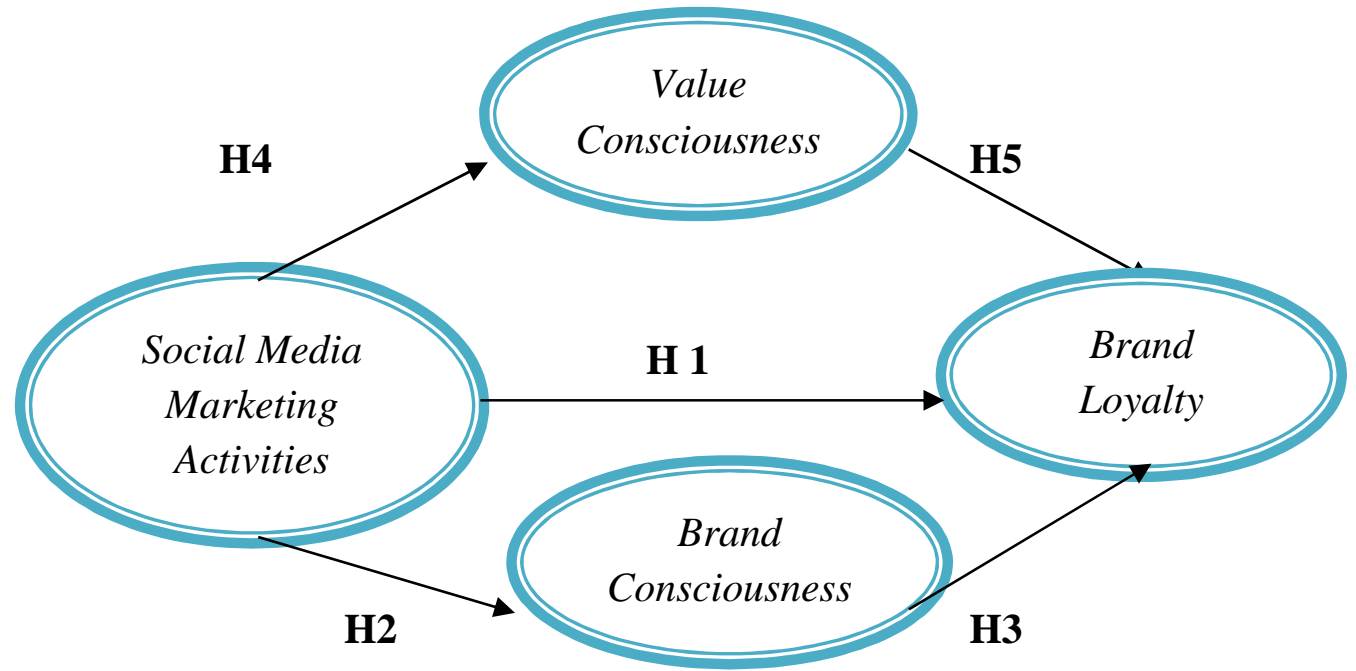

Gambar 1. Model Penelitian 


\section{METODOLOGI PENELITIAN}

\section{Populasi dan Sampel}

Populasi dalam penelitian ini adalah Pelanggan Kopi Janji Jiwa di Kota Surakarta. Teknik pengambilan sampel dalam penelitian ini adalah non probability sampling dan jenis pengumpulan sampel menggunakan purposive sampling karena tidak semua orang dapat memenuhi kriteria minimum sebagai responden. Adapun kriteria responden dalam penelitian ini adalah konsumen Kopi Janji Jiwa di Kota Surakarta, yang mengikuti salah satu akun media sosial Kopi Janji Jiwa (Instagram atau Facebook). Penyebaran kuesioner dilakukan secara daring menggunakan google form. Sampel dalam penelitian ini sebanyak 115 responden.

Tabel 1. Distribusi Karakteristik Responden

\begin{tabular}{|c|c|c|}
\hline Karakteristik & Frekuensi & Jumlah \\
\hline \multicolumn{3}{|c|}{ Jenis Kelamin } \\
\hline Perempuan & 55 & $47,8 \%$ \\
\hline Laki-laki & 60 & $52,2 \%$ \\
\hline \multicolumn{3}{|c|}{ Usia } \\
\hline$<25$ Tahun & 91 & $79,17 \%$ \\
\hline 26 s/d 35 Tahun & 22 & $19,13 \%$ \\
\hline$>36$ & 2 & $1,74 \%$ \\
\hline \multicolumn{3}{|c|}{ Mengetahui Kopi Janji Jiwa } \\
\hline $\mathrm{Ya}$ & 115 & $100 \%$ \\
\hline Tidak & 0 & \\
\hline \multicolumn{3}{|c|}{$\begin{array}{l}\text { Melakukan pembelian digerai kopi } \\
\text { Janji Jiwa Kota Surakarta }\end{array}$} \\
\hline Ya & 115 & $100 \%$ \\
\hline Tidak & 0 & \\
\hline \multicolumn{3}{|c|}{$\begin{array}{l}\text { Mengikuti Instagram Kopi Janji } \\
\text { Jiwa }\end{array}$} \\
\hline $\mathrm{Ya}$ & 105 & $91,3 \%$ \\
\hline Tidak & 10 & $8,7 \%$ \\
\hline \multicolumn{3}{|c|}{$\begin{array}{l}\text { Mengikuti Facebook Kopi Janji } \\
\text { Jiwa }\end{array}$} \\
\hline $\mathrm{Ya}$ & 88 & $76,5 \%$ \\
\hline Tidak & 27 & $23,5 \%$ \\
\hline & $\begin{array}{l}\text { Mengikuti Instagram atau } \\
\text { Facebook Kopi Janji Jiwa }\end{array}$ & \\
\hline
\end{tabular}




\begin{tabular}{ccc} 
Ya & 115 & $100 \%$ \\
\hline
\end{tabular}

Pengukuran variabel Social Media Marketing Activities, Brand Loyalty, Brand Consciousness, dan Value Consciousness dioperasionalkan dengan menggunakan 16 item pernyataan yang diadopsi dari indikator penelitian yang dikembangkan oleh Ismail (2017). Tanggapan menggunakan 5 point Likert skala, yaitu Sangat Tidak Setuju (STS), Tidak Setuju (TS), Netral (N), Setuju (S), Sangat Setuju (SS).

Variabel Independen (X) dalam penelitian ini adalah Social Media Marketing Activities. Variabel Mediasi (M) dalam penelitian ini adalah Brand Consciousness dan Value Consciousness. Variabel Dependen (Y) dalam penelitian ini adalah Brand Loyalty.

a. Brand Loyalty

Brand Loyalty adalah kegiatan pembelian berulang Kopi Janji Jiwa oleh konsumen dalam suatu periode waktu tertentu dengan emosi yang positif. Pengukuran variabel brand loyalty dengan menggunakan 4 item pernyataan yang diadopsi dari indikator penelitian yang dikembangkan oleh (Ismail, 2017).

\section{b. Social Media Marketing Activities}

Social Media Marketing Activities adalah kegiatan pemasaran yang dilakukan Kopi Janji Jiwa melalui media sosial untuk berkomunikasi dengan konsumen secara tidak langsung. Pengukuran variabel social media marketing activities dengan menggunakan 4 item pernyataan yang diadopsi dari indikator penelitian yang dikembangkan oleh Ismail (2017).

\section{c. Brand Consciousness}

Brand Consciousness adalah ingatan yang dimiliki oleh konsumen tentang Kopi Janji Jiwa sehingga dapat membantu kegiatan pemasaran. Ketika konsumen memiliki kesadaran tentang merek Kopi Janji Jiwa, nantinya akan menjadi alternatif untuk pengambilan keputusan dalam pembelian minuman. Pengukuran variabel brand consciousness menggunakan 4 item pernyataan yang diadopsi dari indikator penelitian yang dikembangkan oleh Ismail (2017). 


\section{d. Value consciousness}

Value consciousness adalah nilai yang dirasakan dari perbandingan antara manfaat Kopi Janji Jiwa yang didapat dan pengorbanan yang dilakukan konsumen untuk memperolehnya. Pengukuran variabel value consciousness menggunakan 4 item pernyataan yang diadopsi dari indikator penelitian yang dikembangkan oleh Ismail (2017).

\section{ANALISIS DAN PEMBAHASAN}

\section{Hasil Uji Instrumen Penelitian}

Hasil Uji Validitas menunjukkan bahwa item pernyataan sebanyak 16 item yang menjadi indikator variabel social media marketing activities, brand consciousness, value consciousness, dan brand loyalty dinyatakan valid, karena mempunyai nilai factor loading >0,50. Hasil uji reliabilitas menunjukkan nilai cronbach alpha Social Media Marketing Activities 0,743, Brand Consciousness 0,810, Value Consciousness 0,862, Brand Loyalty 0,864. Semua variable reliabel dinyatakan reliabel, dengan nilai cronbach alpha $>0,60$.

\section{Hasil Uji Hipotesis}

Teknik analisis yang digunakan dalam penelitian ini adalah teknik Structural Equation Modelling (SEM) program aplikasi yang digunakan adalah Analysis Of Moment Structur (AMOS). Langkah kedua adalah pengujian hipotesis untuk hubungan antar variabel menggunakan kriteria Critical Ratio (CR). Penjelasan untuk setiap analisis adalah sebagai berikut:

Tabel 2. Hasil Goodness of Fit

\begin{tabular}{lccc}
\hline \multicolumn{1}{c}{ Goodess of Fit } & Cut of Value & Hasil & $\begin{array}{c}\text { Evaluasi } \\
\text { Model }\end{array}$ \\
\hline Chi Square $\left(x^{2}\right)$ & Diharapkan & & \\
Degress offredom $(p)$ & Kecil & 99,692 & $-\overline{\text { Fit }}$ \\
Probability Level & Positif & 94 & Fit \\
CMIN/DF & $\geq 0,05$ & 0,324 & Fit \\
GFI & $\leq 2,00$ & 1,061 & Fit \\
AGFI & $\geq 0,90$ & 0,907 & Belum Fit \\
TLI & $\geq 0,90$ & 0,866 & Fit \\
CFI & $\geq 0,90$ & 0,988 & Fit \\
RMSEA & $\geq 0,90$ & 0,990 & Fit \\
\hline
\end{tabular}




\section{Analisis Goodness of fit model}

Tabel 2 menjelaskan hasil goodness-of-fit dari model penelitian yang digunakan. Dalam uji ini nilai chi-square $\left(\chi^{2}\right)$ menunjukkan nilai signifikansi lebih dari 0,05 dengan nilai Chi-Square $\left(\chi^{2}\right)$ 99,692. Menunjukkan bahwa model penelitian sudah sesuai dan bisa digunakan. Indeks kesesuaian lainnya yang digunakan adalah $\mathrm{CMN} / \mathrm{DF}=1,061$, Goodness of fit Index $(\mathrm{GFI})=0,907$, Tucker Lewis Index $(\mathrm{TLI})=0,988$, Comparative Fit Index $(\mathrm{CFI})=0,990$ dan Root Mean Square Error of Approxmation (RMSEA) $=0,024$. Secara umum, model yang digunakan menunjukkan tingkat kesesuaian yang baik.

\section{Analisis Regression Weights}

Tabel 3 menunjukkan hasil pengujian Social Media Marketing Activities sebagai variabel Independen, Value Consciousness dan Brand Consciousness sebagai variabel Mediasi, dan Brand Loyalty sebagai variabel Dependen. Hasil pengujian ini menunjukkan bahwa dari lima jalur yang dianalisis, terdapat tiga jalur yang memiliki pengaruh signifikan, terlihat dari besarnya tingkat signifikansi (p) uji hipotesis yang lebih kecil dari 5\% atau 0,05

Tabel 3. Regression Weight

\begin{tabular}{|c|c|c|c|c|c|c|}
\hline & & & Estimate & S.E. & C.R. & $\mathrm{P}$ \\
\hline Value Consciousness & $<-$ & $\begin{array}{l}\text { Social Media } \\
\text { Marketing } \\
\text { Activities }\end{array}$ &, 425 & ,133 & 3,200 & ,001 \\
\hline $\begin{array}{l}\text { Brand } \\
\text { Consciousness }\end{array}$ & $<--$ & $\begin{array}{l}\text { Social Media } \\
\text { Marketing } \\
\text { Activities }\end{array}$ & ,686 &, 160 & 4,281 & ,000 \\
\hline Brand Loyalty & $<--$ & $\begin{array}{l}\text { Social Media } \\
\text { Marketing } \\
\text { Activities }\end{array}$ &, 133 & , 146 & ,909 & ,363 \\
\hline Brand Loyalty & $<--$ & $\begin{array}{l}\text { Value } \\
\text { Consciousness }\end{array}$ &, 058 &, 118 &, 494 & ,621 \\
\hline Brand Loyalty & $<--$ & $\begin{array}{l}\text { Brand } \\
\text { Consciousness }\end{array}$ & ,331 & , 129 & 2,558 &, 011 \\
\hline
\end{tabular}

\section{Pembahasan}


H1: Social media marketing aktivities berpengaruh positif terhadap brand loyalty.

Penelitian yang dilakukan oleh Ismail (2017) merumuskan bahwa social media marketing aktivities berpengaruh positif pada brand loyalty, sedangkan hasil penelitian ini menunjukkan bahwa social media marketing aktivities tidak berpengaruh terhadap brand loyalty. Hal tersebut dimungkinkan karena konsumen dapat dengan mudah memperoleh informasi mengenai berbagai merek lain dengan produk serupa, yang bersaing di media sosial. Dimungkinkan social media marketing aktivities yang dilakukan Kopi Janji Jiwa kurang menarik minat konsumen yang mengakibatkan konsumen lebih tertarik dan melakukan pembelian terhadap merek lain, sehingga konsumen menjadi tidak loyal terhadap merek Kopi Janji Jiwa. Hasil penelitian ini tidak mendukung penelitian Ismail (2017) dan Ismail et al, (2018).

\section{H2: Social media marketing activities berpengaruh positif terhadap brand consciousness.}

Hasil penelitian ini menunjukkan bahwa social media marketing activities berpengaruh positif dan signifikan terhadap brand consciousness. Social media marketing activities dapat meningkatkan brand consciousness saat Kopi Janji Jiwa melakukan komunikasi melalui media sosialnya secara baik dan menarik, maka merek Kopi Janji Jiwa akan semakin melekat di ingatan konsumen. Komunikasi melalui media sosial dapat dilakukan dengan mempromosikan merek, layanan, kualitas produk, dan citra merek, sehingga menimbulkan kesadaran merek di benak konsumen. Hasil penelitian ini mendukung penelitian dari Ismail (2017) dan Hidajat dan Keni (2019) yang mengemukakan bahwa social media marketig activities berpengaruh terhadap brand consciousness.

\section{H3: Brand conciousness berpengaruh positif terhadap brand loyalty.}

Hasil penelitian ini menunjukkan bahwa brand consciousness berpengaruh positif dan signifikan terhadap brand loyalty. Brand consciousness dapat meningkatkan brand loyalty saat merek Kopi Janji Jiwa meninggalkan jejak dibenak konsumen sebagai merek kopi yang memuaskan maka secara sadar konsumen akan kembali mengonsumsinya sehingga brand consciousness 
konsumen dapat meningkatkan brand loyalty Kopi Janji Jiwa. Hasil penelitian ini mendukung penelitian dari Hermanus et. al. (2019) dan Ismail (2017) yang mengemukakan bahwa brand consciousness berpengaruh terhadap brand loyalty.

\section{H4: Social media marketing activities berpengaruh positif terhadap value consciousness.}

Hasil penelitian ini menunjukkan bahwa social media marketing activities berpengaruh positif dan signifikan terhadap value consciousness. Social media marketing activities yang dilakukan Kopi Janji Jiwa menimbulkan value consciousness akan harga, konsumen dengan mudah membandingkan harga antara merek Kopi Janji Jiwa dengan merek lain di social media konsumen masing-masing, untuk mendapatkan nilai terbaik dari produk yang konsumen beli, sehingga Kopi Janji jiwa dapat memperhatikan nilai produk yang akan diunggah dalam social media, terutama terkait harga produk, agar konsumen dapat memperoleh informasi mengenai nilai yang mereka harapkan secara maksimal. Hasil penelitian ini mendukung penelitian dari Ismail et. al. (2018) dan Larasati et. al. (2019) yang mengemukakan bahwa social media marketing activitis berpengaruh terhadap value consciousness.

\section{H5: Value consciousness berpengaruh negatif terhadap brand loyalty.}

Penelitian yang dilakukan oleh Hermanus et.al. (2017) dan Larasati et. al. (2019) merumuskan bahwa Value consciousness berpengaruh negatif terhadap brand loyalty, sedangkan hasil penelitian ini menunjukkan bahwa Value consciousness tidak berpengaruh terhadap brand loyalty. Hal ini dimungkinkan value consciousness konsumen berpengaruh positif terhadap loyalitas, dikarenakan adanya kesadaran akan harga produk, kesadaran nilai produk, potongan harga, dan harga sesuai dengan kualitas yang didapat mampu meningkatan loyalitas merek Kopi Janji Jiwa.

\section{H6: Brand consciousness akan memediasi pengaruh antara social media marketing activities dan brand loyalty.}

Hasil penelitian ini mendukung penelitian dari Hermanus et.al. (2017) dan Hidajat dan Keni (2019), bahwa brand consciousness akan memediasi hubungan antara social media marketing activities dan brand loyalty. Hasil penelitian ini 
https://journal.univetbantara.ac.id/index.php/jbfe

mengemukakan bahwa social media marketing activities berpengaruh terhadap brand consciousness. Brand consciousness berpengaruh terhadap brand loyalty. Maka dapat disimpulkan bahwa brand conciousness dapat memediasi penuh pengaruh social media marketing activities terhadap brand loyalty.

\section{H7: Value consciousness akan memediasi pengaruh antara social media marketing activities dan brand loyalty.}

Penelitian yang dilakukan oleh Ismail (2017) dan Larasati et. al. (2019) merumuskan bahwa value consciousness memediasi hubungan antara social media marketing activities dan brand loyalty, sedangkan hasil penelitian ini menunjukkan bahwa Value consciousness tidak memediasi hubungan antara social media marketing activities dan brand loyalty. Hasil penelitian ini menunjukkan bahwa social media marketing activities berpengaruh terhadap value consciousness. Value consciousness tidak berpengaruh terhadap brand loyalty. Maka dapat disimpulkan bahwa value conciousnes tidak memediasi pengaruh social media marketing activities terhadap brand loyalty.

\section{KESIMPULAN, KETERBATASAN, DAN SARAN}

\section{Kesimpulan}

Berdasarkan penelitian yang dilakukan pada Konsumen Kopi Janji Jiwa di Kota Surakarta, maka dapat diambil kesimpulan bahwa social media marketing activities berpengaruh positif dan signifikan terhadap brand consciousness. Brand conciousness berpengaruh positif dan signifikan terhadap brand loyalty. Social media marketing activities berpengaruh positif dan signifikan terhadap value consciousness. Brand consciousness memediasi pengaruh social media marketing activities terhadap brand loyalty.

\section{Keterbatasan}

Keterbatasan yang ditemui dalam penelitian ini adalah:

1. Metode pengumpulan data dalam penelitian ini adalah menggunakan kuesioner. Namun dalam proses penyebaran kuesioner mengalami kendala, karena penelitian ini dilakukan di masa pandemi Covid-19, yang mengakibatkan kuesioner offline dialihkan menjadi online melalui google 
form, karena harus mematuhi protokol dari pemerintah untuk work from home (WFH) dan social distancing. Maka penelitian ini menggunakan google form, yang memiliki keterbatasan tidak semua orang familiar atau faham dengan google form. Peneliti tidak dapat menjelaskan pernyataan-pernyataan dalam kuesioner pada responden secara langsung.

\section{Saran}

Saran yang dapat diberikan adalah:

1. Saran untuk penelitian selanjutnya

Terkait adanya keterbatasan dalam teknik penyebaran kuesioner, diharapkan untuk mendistribusikan kuesioner secara langsung kepada responden, dengan menambahkan wawancara atau pertanyaan terbuka untuk mengetahui respon responden secara langsung dan lengkap.

2. Saran untuk manajemen Kopi Janji Jiwa

a) Untuk meningkatkan Brand Loyalty, maka manajemen Kopi Janji Jiwa di Kota Surakarta perlu meningkatkan Brand Consciousness, misalnya dengan cara mempromosikan Kopi Janji Jiwa adalah kopi yang kekinian dan berkualitas.

b) Untuk meningkatkan Brand consciousness, maka manajemen Kopi Janji Jiwa di Kota Surakarta perlu meningkatkan Social Media Marketing Activities, misalnya dengan cara meningkatkan informasi terkait dengan merek, produk, layanan Kopi Janji Jiwa, melalui media sosial Kopi Janji Jiwa dan meningkatkan peluang pelanggan untuk memberikan pendapat/review terkait produk, layanan, dan Brand Kopi Janji Jiwa di media sosial. 


\section{DAFTAR PUSTAKA}

APJII (2018). Hasil Survei Penetrasi dan Perilaku Pengguna Internet Indonesia 2018; https://apjii.or.id/sign/signin. Accsessed 24.03.2020

Bao, Y. and Mandrik, C.A. (2004), “Discerning store brand users from value consciousness consumers:the role of prestige sensitivity and need for cognition", Advances in Consumer Research, Vol. 31No. 1, pp. 707-712.

Bisnis.com. (2019).Startup Kopi Menjamur, Persaingan Bisnis Kafe di Indonesia Memanas. https://ekonomi.bisnis.com/read/20190807/12/1133701/startupkopi-menjamur-persaingan-bisnis-kafe-di-indonesia-memanas. Accsessed 13$10-2020$

economy.okezone (2020). 7 Milenial Bisnis Kedai Kopi, dari Kaesang hingga BosKopiKenangan; https://economy.okezone.com/read/2020/06/12/320/22287 22/7-milenial-bisnis-kedai-kopi-dari-kaesang-hingga-bos-kopi-kenangan. Accessed 23.03.2020. Accsessed 15-10-2020

Fatwa, I., Larasati, Q., Yohanes A. L., Aprilvianto,\& Muhammad F. U. (2019), “ Value Consciousness As A Mediation To Brand Loyalty On The Indonesian Retai ", Proceeding Book 7th Asian Academic Society International Conference 2019. ISBN: 978-602-61265-5-9

Hermanus, A. E., Silvia. M., \& Indarini , (2019), "The Impact Of Social Media Marketing On Brand Loyalty: The Mediation Effect Of Brand-Value Consciousness Towards Adidas Brand In Indonesia", Journal of Management and Business, Vol. 15, No. 2.

Hidajat S., dan Keni. (2019). Prediksi Social Media Marketingdan Brand Uniqueness

Terhadap Brand Loyalty: Brand Consciousness Sebagai Variabel Mediasi.Jurnal Manajerial dan Kewirausahaan, Volume I No. 2/2019 Hal: 325-334.

Ismail, A.R. (2017). The influence of perceived social media marketing activities on brand loyalty: The mediation effect of brand and value consciousness. Asia Pacific Journal of Marketing and Logistics. Vol. 29. No. 1. pp. 129-144.

Ismail A.R. et. al, (2018). Impact of perceived social media marketing activities on brand and value consciousness: roles of usage,materialism and conspicuous consumption. Int. J. Internet Marketing and Advertising, Vol. 12, No. 3, 2018

KONTAN.CO.ID. (2019).Persaingan kian sengit, ini strategi agar usaha kedai kopi tetap legit.https://peluangusaha.kontan.co.id/news/persaingan-kian-sengit-inistrategi-agar-usaha-kedai-kopi-tetap-legit-1. Accsessed 16-10-2020

Mangold, W. G., \& Faulds, D. J. (2009). Social media: The new hybrid element of the promotion mix. Business Horizons, 52(4), 357-365. 
Merisavo, M. and Raulas, M. (2004), "The impact of email marketing on brand loyalty", Journal ofProduct and Brand Management, Vol. 13 No. 7, pp. 498505.

Tim MURI. (2019). Pertumbuhan Kedai Kopi Tercepat dalam Satu Tahun. https://muri.org/pertumbuhan-kedai-kopi-tercepat-dalam-satutahun/?openmodal=true . Accsessed 17-10-2020.

Phau, Ian dan Min Teah. (2009). Devil Wears (Counterfeit) Prada: A Study of Antecedents and Outcomes of Attitudes towards Counterfeits of Luxury Brands. Journal of ConsumerMarketing 26/1 15-27.

Rahmadiane, G. D. (2016). Pengaruh Value Consciousness, Integrity, dan Perceived Ease To Get Product Terhadap Sikap dan Niat Beli Barang Palsu di Kota Tegal. Journal Research Accounting Politeknik Tegal.

Sasmita, J., dan Suki, N. M. (2014). Young Consumers's Insights on Brand Equity. International Journal of Retail \& Distribution Management, 43 (3), 276-292. Diambil dari Emerald Insight.

Sharda N, dan Anil B., (2019). Mediating effect of brand consciousness. Journal of Product \& Brand Management. Volume 28 · Number $7 \cdot 201$

Sharma, P. (2011), "Country of origin effects in developed and emerging markets: exploring the contrasting roles of materialism and value consciousness", Journal of International Business Studies, Vol. 42 No. 2, pp. 285-306.

Sorescu, A., Frambach, R.T., Singh, J., Rangaswamy, A. dan Bridges, C. (2011), "Innovations in retail business models". Journal of Retailing. Vol. S87 No. 1, pp. S3-S16. 


\section{LAMPIRAN KUESIONER}

Pernyataan di bawah ini terkait dengan Social Media Marketing Activities Kopi Janji Jiwa

\begin{tabular}{|c|c|c|c|c|c|c|}
\hline No & Pernyataan & STS & TS & $\mathbf{N}$ & $\mathbf{S}$ & SS \\
\hline 1 & $\begin{array}{l}\text { Saya menggunakan media sosial untuk mencari } \\
\text { informasi tentang merek Kopi yang sedang tren } \\
\text { sekarang seperti Kopi Janji Jiwa }\end{array}$ & & & & & \\
\hline 2 & $\begin{array}{l}\text { Saya menemukan konten yang menarik dalam } \\
\text { media sosial tentang merek Kopi Janji Jiwa, } \\
\text { Kemudian saya tertarik untuk membelinya }\end{array}$ & & & & & \\
\hline 3 & $\begin{array}{l}\text { Saya mudah menyuarakan pendapat saya di } \\
\text { media sosial terkait Kopi Janji Jiwa yang saya } \\
\text { beli. }\end{array}$ & & & & & \\
\hline 4 & $\begin{array}{l}\text { Saya ingin menyampaikan informasi terkait } \\
\text { Kopi Janji Jiwa tentang merek, produk, atau } \\
\text { layanan di media sosial kepada teman saya }\end{array}$ & & & & & \\
\hline
\end{tabular}

Pernyataan di bawah ini terkait dengan Brand Consciousness Kopi Janji Jiwa

\begin{tabular}{|c|l|l|l|l|l|l|}
\hline No & \multicolumn{1}{|c|}{ Pernyataan } & STS & TS & N & S & SS \\
\hline 1 & $\begin{array}{l}\text { Saya sadar produk kopi yang akan saya beli } \\
\text { adalah kopi merek Janji Jiwa }\end{array}$ & & & & \\
\hline 2 & $\begin{array}{l}\text { Saya sadar merek Janji Jiwa memberi tahu saya } \\
\text { tentang kualitas kopi }\end{array}$ & & & & & \\
\hline 3 & $\begin{array}{l}\text { Terkadang saya bersedia mengeluarkan biaya } \\
\text { lebih untuk membeli kopi pada merek Janji } \\
\text { Jiwa }\end{array}$ & $\begin{array}{l}\text { Kopi dari merek Janji Jiwa memiliki harga } \\
\text { mahal dengan kualitas yang baik }\end{array}$ & & & \\
\hline
\end{tabular}


https://journal.univetbantara.ac.id/index.php/jbfe

Pernyataan di bawah ini terkait dengan Value Consciousness Kopi Janji Jiwa

\begin{tabular}{|c|c|c|c|c|c|c|}
\hline No & Pernyataan & STS & TS & $\mathrm{N}$ & $\mathrm{S}$ & $\mathrm{SS}$ \\
\hline 1 & $\begin{array}{l}\text { Saya sangat sadar akan harga yang murah tetapi } \\
\text { saya juga peduli dengan kualitas pada Kopi } \\
\text { Janji Jiwa }\end{array}$ & & & & & \\
\hline 2 & $\begin{array}{l}\text { Ketika saya membeli Kopi Janji Jiwa, saya } \\
\text { akan membandingkan harga dari berbagai kopi } \\
\text { yang berbeda, untuk memastikan bahwa saya } \\
\text { mendapat nilai terbaik untuk uang yang saya } \\
\text { keluarkan }\end{array}$ & & & & & \\
\hline 3 & $\begin{array}{l}\text { Ketika saya membeli kopi Janji Jiwa, saya } \\
\text { selalu berusaha memaksimalkan kualitas yang } \\
\text { saya dapatkan untuk uang yang saya keluarkan }\end{array}$ & & & & & \\
\hline 4 & $\begin{array}{l}\text { Saat membeli kopi Janji Jiwa, saya ingin } \\
\text { memastikan bahwa saya mendapat kelayakan } \\
\text { atas uang yang saya keluarkan. }\end{array}$ & & & & & \\
\hline
\end{tabular}

Pernyataan di bawah ini terkait dengan Brand Loyalty Kopi Janji Jiwa

\begin{tabular}{|c|l|l|l|l|l|l|}
\hline No & \multicolumn{1}{|c|}{ Pernyataan } & STS & TS & N & S & SS \\
\hline 1 & $\begin{array}{l}\text { Saya lebih sering membeli kopi merek Janji } \\
\text { Jiwa daripada membeli merek kopi lain }\end{array}$ & & & & & \\
\hline 2 & $\begin{array}{l}\text { Saya yakin jenis merek kopi yang selalu saya } \\
\text { beli adalah Janji Jiwa }\end{array}$ & & & & \\
\hline 3 & $\begin{array}{l}\text { Saya merasa setia pada satu merek produk } \\
\text { kopi yaitu Janji Jiwa }\end{array}$ & $\begin{array}{l}\text { Saya merasa percaya diri ketika membeli Kopi } \\
\text { dengan merek Janji Jiwa }\end{array}$ & & & & \\
\hline
\end{tabular}

